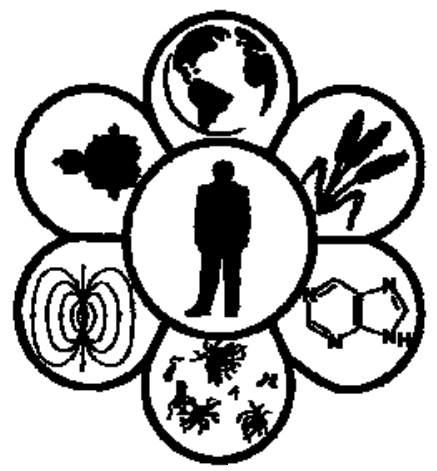

Вісник Дніпропетровського університету. Біологія, медицина Vìsnik Dnìpropetrovs'kogo unìversitetu. Seriâ Bìologiâ, medicina

Visnyk of Dnipropetrovsk University. Biology, medicine

Vìsn. Dnìpropetr. Unìv. Ser. Bìol. Med. 2014. 5(1), 33-38.

doi:10.15421/021407

ISSN 2310-4155 print

ISSN 2312-7295 online

www.medicine.dp.ua

УДК 579.842.1

\title{
Механізми стійкості до антибіотиків представників родини Enterobacteriaceae
}

\author{
К.Р. Коцюба, О.С. Воронкова, А.І. Вінніков, Т.М. Шевченко
}

Дніпропетровський національний університет імені Олеся Гончара, Дніпропетровськ, Украӥна

\begin{abstract}
Наведено характеристику ентеробактерій та показано їх роль у патології людини. Проаналізовано відомості про головні напрями антибіотикотерапії уражень, зумовлених представниками родини Enterobacteriaceae, подано матеріали про проблеми антибіотикотерапії, пов'язані з поширенням серед них детермінант резистентності до антибіотиків. Лікування ентеробактеріальних інфекцій здійснюється із використанням бета-лактамів, хінолонів, аміноглікозидів і ряду препаратів вузьконаправленої дії. Лікуванню обов'язково повинні передувати ідентифікація збудника, бо серед ентеробактерій існує феномен природної стійкості до ряду препаратів, та дослідження рівня чутливості кожного конкретного ізолята до антибіотиків через значне поширення стійкості до багатьох із них. Таке дослідження необхідне для розробки схеми раціональної антибіотикотерапії та недопущення подальшого поширення детермінант резистентності всередині та поза межами групи. У зв'язку з цим особливого значення набуває питання контролю за рівнем розповсюдження антибіотикостійких ізолятів у лікарнях і лікувально-профілактичних закладах, що потребує постійного контролю з боку відповідних органів.
\end{abstract}

Ключові слова: ентеробактерії; антибіотикотерапія; стійкість до антибіотиків

\section{Mechanisms of antibiotic resistance of Enterobacteriaceae family representatives}

\author{
K.R. Kotsyuba, O.S. Voronkova, A.I. Vinnikov, T.M. Shevchenko \\ Oles Honchar Dnipropetrovsk National University, Dnipropetrovsk, Ukraine
}

\begin{abstract}
The paper deals with the basic medical scheme of antibiotics use for treatment of lesions caused by enterobacteria and mechanisms of resistance of Enterobacteriaceae to different classes of antibiotics. It is known that the main mechanisms of resistance to antibiotics are enzymatic inactivation, modification of the target, efflux, violation of conduct through the membrane and formation of metabolic shunt. The most common cases of resistance to beta-lactams among Enterobacteriaceae relate to production of plasmid and chromosomal beta-lactamases, violation of the permeability of the outer membrane, and modification of target penicillin binding proteins. Active release of antibiotics from the cell, or efflux, in Enterobacteriaceae is used for maintaining resistance to tetracyclines, macrolides, carbapenems. Genes of efflux system are localized on plasmids and contribute to rapid spreading among Enterobacteriaceae. Mutations are the basis of resistance to novobiocinum and rifampicinum. Enzymatic inactivation by modifying is typical for resistance to aminoglycosides. Three groups of enzymes are engaged in the process, by adding the molecule of acetic acid, phosphate or adenine. Joining of these groups is irreversible and leads to complete loss of biological activity of the antibiotic. Resistance to aminoglycosides appears also due to inhibition of drug penetration, that is associated with genetically determined mechanisms of electron transport through the membrane. Resistance to quinolones and fluoroquinolones is associated with the modification of topoisomerase II and IV which are targets of these groups of antibiotics. Resistance is possible as a result of changes in the structure of the target, breaching of penetration into the cell, and active release from the cell. The highest level of resistance is develope in the case of two- or three-stage mutations in one or the other, or both, subunits in different genes. At the same time, for breaching of the bacterial cell it is enough to suppress the activity of only one enzyme associated with different functions of both topoisomerases. Another mechanism of resistance to quinolones is the reduction of permeability through bacterial outer membrane, that it's possible due to decreasing of permeability of porine channels. In this case, decreasing of permeability efficacy takes place not only for quinolones, but also for other classes of antibitics. In addition, reduced sensitivity to quinolones efflux may play the significant role. For clinical strains of microorganisms, cross-resistance to various drugs, associated with simultaneous production of various enzymes that inactivate antibiotics, is typical.
\end{abstract}

Keywords: enterobacteria; antibiotic therapy; antibiotic resistance

Дніпропетровський наџіональний університет імені Олеся Гончара, пр. Гагаріна, 72, Дніпропетровськ, 49010, Украӥна. Oles Honchar Dnipropetrovsk National University, pr. Gagarina, 72, Dnipropetrovsk, 49010, Ukraine.

Tel.: +38-067-790-70-92.E-mail:a_vinnikov@ukr.net 


\section{Вступ}

Структура інфекційної патології людини останніми десятиліттями суттєво змінюється не лише через зміну в ній питомої частки захворювань, зумовлених добре відомими збудниками, а і завдяки ролі, яку стали відігравати нові інфекційні агенти, кількість яких невпинно зростає за рахунок умовно-патогенних мікроорганізмів (Sidorenko, 2003; Tsiganenko and Girich, 2009). Представники родини Enterobacteriaceae - невід'ємна складова біосфери. Завдяки полібіотрофії та адаптаційній пластичності вони широко розповсюджені в об'єктах навколишнього середовища абіотичної природи, в організмах рослин і тварин. Життедіяльність цих бактерій суттєво впливає на різні сфери діяльності людини. Упродовж усього періоду розвитку медичної мікробіології ентеробактерії постійно були об'єктом підвищеної уваги фахівців наукових установ і практичних закладів охорони здоров'я. Причина цього - надзвичайний поліморфізм клінічного перебігу інфекційного процесу (можуть уражатись усі системи та органи людського організму) та постійно високий рівень захворюваності, спричинений цією групою бактерій, у тому числі внутрішньогоспітальних інфекцій (Pozdeev, 2001; Vorobyov, 2004).

Різноманіття біологічних властивостей ентеробактерій значно ускладнює етіологічну лабораторну діагностику зумовлених ними захворювань. Найбільші труднощі становлять нові (вперше описані) та маловивчені види через обмеженість відомостей про біоекотопи та ареали їх циркуляції, біологічні властивості (у тому числі їх патогенний потенціал і санітарно-бактеріологічне значення), недостатню розробленість методів виділення та ідентифікації цих мікроорганізмів (Pozdeev, 2001; Bao et al., 2013).

Enterobacteriaceae - велика родина бактерій, що включає такі відомі патогенні бактерії як Salmonella, Escherichia coli (ентеропатогенні), Yersinia pestis тощо. Безліч представників родини $є$ частиною нормальної мікрофлори людей і тварин, тоді як інші мешкають у грунті, воді або паразитують на різних рослинах і тваринах. Більшість симбіотичних (зокрема паразитичних) видів родини використовують численні ворсинки I типу для адгезії до клітин хазяїна (Decousser et al., 2003; Bonelli et al., 2014).

Протягом останніх 15-20 років зросло значення різних ентеробактерій у патології людини. Насамперед це пов'язано з набуттям ентеробактеріями значної кількості детермінант резистентності до антибіотиків, якими вони активно обмінюються між штамами (Sidorenko, 2003; Bao et al., 2013).

Сучасний етап розвитку медичної науки та практики характерний виникненням проблеми умовно-патогенних мікроорганізмів та їх ролі у патології людини. За певних умов у так званих групах ризику етіологічного значення можуть набувати найрізноманітніші опортуністичні бактерії. У виникнення умовно-патогенних мікроорганізмів виявились втягнутими численні роди кишкових бактерій - Escherichia, Citrobacter, Klebsiella, Enterobacter, Hafnia, Serratia, Yersinia тощо. Це пред'являє суттєво більші вимоги до діяльності медичних бактеріологів, до їх роботи 3 ідентифікації та диференціальної діагностики численних членів родини Enterobacteriaceae. Великого значення ця група бактерій останнім часом також набуває через значне поширення серед іiі представників детермінант резистентності до антибіотиків, що значно ускладнює терапію певних типів уражень (Pozdeev, 2001; Shapiro, 2002).

Мета роботи полягає в огляді відомостей про проблему антибіотикорезистентності ентеробактерій, що мають клінічне значення.

\section{Лікування уражень, зумовлених ентеробактеріями}

Основу хіміотерапії ешерихіозів складає призначення ефективних антимікробних засобів (ампіцилін, котримоксазол, норфлоксацин тощо). Для лікування інфекцій сечовивідних шляхів також використовують цефалоспорини та аміноглікозиди. Засобів специфічної імунопрофілактики немас. Профілактика колі-інфекції спрямована на дотримання санітарно-гігієнічних правил, попередження інфікування продуктів харчування та розмноження в їжі мікроорганізмів, знищення прониклих мікробів за допомогою термічної обробки (Shapiro, 2002; Sidorenko, 2003).

Лікування тяжких ентеробактеріальних інфекцій грунтується на застосуванні бета-лактамів, хінолонів, аміноглікозидів і ряду препаратів вузьконаправленої дії (у зв'язку з особливостями фармакокінетики окремих антибіотиків у шлунково-кишковому тракті та сечовивідних шляхах, а також із відмінностями їх клінічної ефективності). Окрім даних про чутливість збудників, під час вибору конкретних препаратів необхідно оріснтуватися також на особливості нозологічної форми та тяжкість перебігу процесу (Beloborodova et al., 2000; Stratchounski et al., 2007). Практично в усіх представників родини Enterobacteriaceae, за винятком сальмонел, до складу хромосом входять гени бета-лактамаз. Схема природної чутливості ентеробактерій до бета-лактамних антибіотиків $є$ фундаментом сучасної хіміотерапії інфекцій, викликаних цими мікроорганізмами. Проте слід мати на увазі, що набута резистентність може повністю змінити цю картину. Саме з метою визначення набутої стійкості проводяться мікробіологічні дослідження (Greenwood, 1998; Bereznyakov, 2001; Decousser, 2003).

До природних препаратів пеніцилінового ряду, що вважаються найбезпечнішими для людини, чутливі тільки деякі грампозитивні бактерії; кишкова паличка та інші грамнегативні мікроорганізми стійкі. Тому призначення природних пеніцилінів при інфекціях, зумовлених ентеробактеріями, не обгрунтоване. Водночас, амінопеніциліни характеризуються значною природною активністю проти деяких грамнегативних бактерій (E. coli, Proteus mirabilis тощо). Але ї застосування потребує моніторингу стійкості до них.

Цефалоспорини I покоління слабко діють на $E$. coli, щодо інших ентеробактерій практично не активні. Цефалоспорини II покоління за активністю проти кишкової палички та рівня набутої стійкості поступаються фторхінолонам і пероральним цефалоспоринам III покоління, тому не розглядаються як засоби вибору для лікування інфекцій, викликаних ентеробактеріями. Препарати III покоління проявляють високу активність проти 
грамнегативних мікроорганізмів, тому часто призначаються. Рівень стійкості $E$. coli до цефіксиму та цефтибутену $<5 \%$, тому ці антибіотики можуть вважатися одними 3 найефективніших. Цефалоспорини IV покоління цікаві при терапії уражень, викликаних госпітальними штамами, серед яких відмічається менший рівень стійкості до них (Gupta and Bhadelia, 2013).

До карбапенемів відмічається найменший рівень стійкості госпітальних штамів Enterobacteriaceae, тому їх використовують лише у разі виділення мультирезистентних грамнегативних збудників.

Аміноглікозиди проявляють високу природну активність проти грамнегативних бактерій, однак їх застосування лімітує потенційна нефротоксичність. Їх використовують у разі виявлення стійкості до безпечніших препаратів, призначення аміноглікозидів в амбулаторній практиці вважається абсолютно не припустимим.

Грамнегативні бактерії мають природну стійкість до макролідів, тому їх призначення для лікування інфекцій, викликаних ентеробактеріями, безглузде. Те ж саме стосується лінкозамідів, які не діють на грамнегативні бактерії.

Доксициклін (препарат із групи доксициклінів) має високу природну активність проти кишкової палички та деяких ентеробактерій. Однак зараз значення доксицикліну обмежене через наявність ефективніших і безпечніших антибіотиків. Доксициклін розглядається здебільшого як препарат вибору.

Нефторовані хінолони проявляють виняткову активність щодо грамнегативних мікроорганізмів і до появи фторованих хінолонів їх розглядали як засоби вибору за багатьох інфекцій, зумовлених грамнегативними мікроорганізмами. У даний час їх значення у практиці обмежене. Фторхінолони I покоління проявляють високу природну активність проти Enterobacteriaceae. Серед ранніх фторхінолонів максимальну активність проти грамнегативних бактерій проявляє ципрофлоксацин. Однак на вибір цих препаратів впливає рівень набутої резистентності. Для позалікарняних штамів рівень стійкості до фторхінолонів невисокий (до всіх препаратів приблизно однаковий), а в госпітальних штамів грамнегативних бактерій він істотно варіює у різних медичних установах. Обмеженням використання фторхінолонів $є$ їх шкідлива дія на зростаючий хрящ, у зв’язку з чим ці препарати не можна призначати вагітним жінкам і дітям до 16 років. Фторхінолони II покоління мають подібну 3 ранніми фторхінолонами активність проти грамнегативних бактерій (Gupta and Bhadelia, 2013; Yakovlev, 2004).

Нітрофурани мають широкий спектр дії відносно більшості ентеробактерій. До переваг цих препаратів слід віднести невисокий рівень стійкості позалікарняних штамів E. coli.

Ко-тримоксазол - позагруповий препарат, що проявляє активність проти Enterobacteriaceae. Однак останнім часом відмічається зростання стійкості позалікарняних і госпітальних штамів E. coli та інших ентеробактерій до нього, що знижує його терапевтичну цінність. Крім того, препарат може викликати серйозні побічні ефекти.

Ще один позагруповий препарат фосфоміцин характеризується високою активністю проти E. coli та інших ентеробактерій (Yakovlev, 2004).
Лікування уражень, викликаних ентеробактеріями, багато в чому залежить від характеру зараження, а також від ділянки ураження. Спочатку пацієнту потрібно здати аналізи для того, щоб визначити вид збудника, адже серед ентеробактерій поширений феномен природної стійкості до ряду препаратів. Крім того, лабораторне дослідження обов'язково має включати антибіотикограму - аналіз чутливості досліджуваного мікроорганізму до антибіотиків. Нині відома велика кількість різноманітних антибіотиків, і з цієї причини оптимальним варіантом для розробки схеми раціональної терапії ураження може бути перевірка чутливості бактерій до дії певного препарату. Результати антибіотикограми дозволяють обрати 3 ряду препаратів найефективніший і найменше шкідливий для організму людини (Yakovlev, 2004; Stratchounski et al., 2007).

\section{Механізми антибіотикорезистентності ентеробактерій}

Загалом слід зазначити, що ентеробактерії - один із найпроблемніших збудників інфекцій серед умовнопатогенних мікроорганізмів саме через значну поширеність серед них генів резистентності. Як серед позалікарняних, так і серед внутрішньолікарняних інфекцій кишкової та позакишкової локалізації (інфекції сечовивідних, дихальних шляхів, інтраабдомінальні, шкіри та м'яких тканин, а також генералізовані) доволі часто трапляються випадки, зумовлені множинностійкими ентеробактеріями.

Основними механізмами стійкості до бета-лактамних антибіотиків в ентеробактерій $є$ продукція плазмідних і хромосомних бета-лактамаз, порушення проникності зовнішньої мембрани, модифікація мішені пеніцилінз'вязувальних білків - ПЗБ (Beloborodova, 2000; Bereznyakov, 2001; Bao et al., 2013).

Продукція бета-лактамаз зумовлює приблизно 80\% випадків стійкості до бета-лактамних антибіотиків серед ентеробактерій. Здатність до продукції цих ферментів виявлена у багатьох представників родини. Нині описано понад 200 ферментів, що розрізняються за субстратним профілем (здатність до переважного гідролізу тих або інших бета-лактамів, наприклад пеніцилінів або цефалоспоринів, або тих і інших рівною мірою), локалізацією генів, що кодують стійкість (плазмідна або хромосомна) (Livermore, 2005; Lee et al., 2013; Pfaller et al., 2014).

У разі плазмідної локалізації генів відбувається швидке внутрішньо- та міжвидове поширення резистентності, хромосомної - спостерігається поширення резистентного клону (Nilsen et al., 2013), чутливість до інгібіторів, що застосовуються в медичній практиці: клавуланової кислоти, сульбактаму та тазобактаму (Stratchounski et al., 2007).

Серед грамнегативних бактерій продукція беталактамаз - одна з найчастіших причин резистентності. Бета-лактамази грамнегативних мікроорганізмів поділяють на дві групи: кодовані плазмідними або хромосомними генами. Нині найбільше значення для клінічної практики мають плазмідні бета-лактамази розширеного спектра (БЛРС) грамнегативних бактерій, оскільки вони здатні руйнувати усі бета-лактамні антибіотики, включаючи цефалоспорини III і меншою мірою IV покоління; 
винятком є тільки карбапенеми (Stratchounski et al., 2007; Cochard et al., 2014; Pfaller et al., 2014). Розвиток плазмідної резистентності нерідко пов'язаний із використанням ампіциліну та цефалоспоринів III покоління (усі цефалоспорини III покоління створюють проблеми резистентності, навіть якщо їх призначають у невеликих кількостях) (Thibaut et al., 2014; Veldman et al., 2014). Звичайні лабораторні методи оцінки чутливості до антибіотиків нерідко не виявляють цього механізму стійкості. Частіше усіх БЛРС зустрічаються в мікроорганізмів роду Klebsiella, досить часто - у E. coli та Proteus spp., рідше - в інших грамнегативних бактерій (Stratchounski et al., 2007; Cochard et al., 2014).

Хромосомні бета-лактамази, як правило, виробляються в невеликих кількостях (Decousser et al., 2003; Grover et al., 2012). Проте під впливом деяких беталактамних антибіотиків їх синтез різко зростає. Із цим пов'язаний механізм резистентності до амінопеніцилінів і цефалоспоринів I покоління у Enterobacter cloacae, Serratia spp., Citrobacter spp., Proteus spp. (Thibaut et al., 2014; Veldman et al., 2014). Вищевказані антибіотики є сильними індукторами ферментів, вони високочутливі до гідролізу. Enterobacter cloacae здатний до гіперпродукції хромосомних бета-лактамаз, із чим і пов'язана стійкість до більшості беталактамних антибіотиків, за винятком карбапенемів (Lee et al., 2013). Клебсієли продукують бета-лактамази розширеного спектра, чим також зумовлена стійкість до більшості цефалоспоринів (окрім цефаміцинів) при збереженні чутливості до карбапенемів (Nakamura et al., 2014; Veldman et al., 2014). Проте карбапенеми не $є$ винятком із загального правила. До них також можливе формування резистентності, пов'язаної з продукцією карбапенемаз (Liu et al., 2014).

Стійкість до бета-лактамних антибіотиків, пов'язана 3 порушенням проникності клітинної оболонки, характеризується раптовим або поступовим розвитком перехресної резистентності одного виду бактерій до інших антибіотиків. Виникнення цього типу стійкості пов'язане 3 використанням аміноглікозидів i беталактамних антибіотиків для лікування інфекцій, викликаних ентеробактеріями (Greenwood, 1998). Зовнішня мембрана грамнегативних мікроорганізмів $є$ перешкодою для проникнення бета-лактамів усередину клітини. Транспорт антибіотика через зовнішню мембрану до чутливих мішеней здійснюється через воронкоподібні білкові структури, що дістали назву «поринові канали» (Nikaido and Normark, 1987; Nikaido et al., 1991). У peзультаті мутацій можлива повна або часткова втрата поринів, що спричинює різною мірою виражене зниження чутливості до бета-лактамних антибіотиків (Nikaido et al., 1991).

Антибіотики пеніцилінового ряду мають різну активність до різних видів. У межах родини ентеробактерій виділені три групи мікроорганізмів, які різняться за природною чутливістю до пеніцилінів: I група - E. coli, Shigella spp., Salmonella spp., Proteus mirabilis; II група Klebsiella spp., Proteus vulgaris, Citrobacter diversus; III група - Enterobacter spp., Citrobacter freundii, Serratia spp., Morganella morganii, Providencia stuartii, Providencia rettregeri (Vorobyov, 2004). На відміну від грампозитивніих бактерій, протективні властивості ПЗБ у грамнегативних бактерій виражені слабко (в ентероба- ктерій вони майже повністю відсутні) (Bereznyakov, 2001). Активне виведення антибіотиків із клітини, або ефлюкс, має місце й у ентеробактерій. Однак активність цього процесу різна в окремих видів. Такий механізм стійкості бактерій має місце відносно тетрациклінів, макролідів, карбапенемів і посідає помітне місце у підвищенні загальної резистентності мікроорганізмів. Гени, відповідні за кодування транспортних систем активного винесення із клітин антибіотиків, звичайно локалізовані на плазмідах, що сприяє їх швидкому поширенню всередині родини, особливо серед мікроорганізмів різних видів, які перебувають у єдиному біотопі (Kohler et al., 1997; Bao et al., 2013).

У результаті різних мутагенних впливів на чутливу до того або іншого антибіотика мікробну клітину можна отримати мутант зі зміненою ферментною системою, що $\epsilon$ мішенню для антибіотика. Такий мутант може виявитися резистентним до антибіотика. Аналогічним шляхом отримані резистентні мутанти E. coli до таких антибіотиків як новобіоцин, рифаміцин і деякі інші (Drees et al., 2014; Randrianirina et al., 2014).

Подібний до механізмів стійкості до пеніцилінів і механізм стійкості до аміноглікозидів: у клітині відбувається їх ферментативна інактивація шляхом модифікації. Модифіковані молекули аміноглікозидів втрачають здатність зв'язуватися з рибосомами та пригнічувати синтез білка. Описано три групи ферментів, які здійснюють таку інактивацію шляхом зв'язування з різними молекулами: ААС-ферменти приєднують молекулу оцтової кислоти, АРН-ферменти приєднують фосфат, нуклеотиділ- або ANT-ферменти приєднують молекулу нуклеотиду аденіну. Приєднання цих груп необоротне, воно спричинює втрату біологічної активності антибіотика (Sidorenko et al., 1998).

Механізми, що визначають стійкість ентеробактерій до аміноглікозидів за рахунок модифікації препаратів, набуті (Miller, 1996). Також існують і природні механізми стійкості, які реалізуються за рахунок гальмування проникнення препарату. В останньому випадку значення мають генетично зумовлені механізми електронного транспорту через мембрану. Проходженню аміноглікозидами цитоплазматичної мембрани сприяє система електронного транспорту. Підтвердженням цього вважають високу резистентність до аміноглікозидів в анаеробних бактерій, дефіцитних по електронтранспортній системі, що може мати місце в ентеробактерій, які зростають в анаеробних умовах (Miller, 1996; Vorobyov, 2004).

Для клінічних штамів мікроорганізмів характерна частково перехресна резистентність до різних препаратів, що пов'язано з можливістю одночасної продукції різних ферментів, які інактивують аміноглікозиди. Резистентність до канаміцину, як правило, сполучається зі стійкістю до мономіцину. Грамнегативні мікроорганізми, що проявляють резистентність до стрептоміцину, у більшості випадків чутливі до всіх інших аміноглікозидів. Бактерії, стійкі до аміноглікозидів I покоління (стрептоміцин, неоміцин, мономіцин, канаміцин), зберігають чутливість до гентаміцину та аміноглікозидів II-III поколінь. У той же час резистентність до гентаміцину супроводжує стійкість до всіх аміноглікозидів I покоління (Miller, 1996; Bereznyakov, 2001). 
Провідним механізмом стійкості до хінолонів і фторхінолонів є модифікація мішеней їх дії: топоізомераз II i IV, що опосередковують конформаційні зміни молекул бактеріальної ДНК, необхідні для її нормальної реплікації. В основі розвитку резистентності мікроорганізмів до хінолонів і фторхінолонів лежать три основні механізми: зміна структури ферментів-мішеней (ДНК-гірази та топоізомерази IV), порушення проникнення в клітину, активне виведення із клітини (Drlica, 1997). Найбільшу спорідненість хінолони проявляють до ДНК-гірази, завдяки чому саме цей фермент є первинною мішенню їх діï. Основним механізмом стійкості є зміна структури топоізомераз у результаті мутацій у відповідних генах і амінокислотних замінах у молекулах ферментів. Амінокислотні заміни, у свою чергу, викликають зниження спорідненості хінолонів до ферментів і підвищення мінімальної пригнічувальної концентрації (МПК) цих препаратів. Частота виникнення мутацій, імовірно, мало залежить від впливу хінолонів, однак формування стійких штамів можливе лише в результаті селекції на тлі дії препаратів. У переважній більшості випадків стійкість формується ступінчасто. Після виникнення та селекції мутацій у генах ферменту, що $є$ первинною мішенню дії хінолонів, МПК препаратів звичайно підвищується в 4 8 разів, а антибактеріальний ефект проявляється за рахунок пригнічення активності ферменту, що $є$ вторинною мішенню. Якщо вплив хінолонів на мікроорганізм триває, то можливе виникнення та селекція мутацій у вторинній мішені та, як наслідок, підвищення МПК ще в 4-8 разів. У штамів бактерій із високим рівнем стійкості звичайно виявляють декілька мутацій у генах обох топоізомераз (Drlica, 1997; Yakovlev, 2004). Найвищий рівень резистентності розвивається у випадках дво- чи триступінчастих мутацій по тій або інший субодиниці або одночасно в різних генах. Для порушення розвитку бактеріальної клітини буває досить пригнічення активності тільки одного ферменту, що пов'язано з різними функціями двох топоізомераз. 3 огляду на те, що гени обох ферментів локалізовані на бактеріальній хромосомі, резистентність до фторхінолонів має хромосомну природу, яка має перехресний характер у межах групи хінолонів. Однак рівень резистентності до фторхінолонів значно нижчий, що визначає високу клінічну активність фторхінолонів стосовно більшості резистентних до нефторованих хінолонів штамів бактерій (Yakovlev, 2004).

Ще один механізм стійкості до хінолонів - зниження проникності зовнішньої мембрани бактерій за рахунок ушкодження проникності поринових каналів або ліпополісахаридного шару. У цьому випадку знижується проникність мембрани не тільки для хінолонів, а і для антибактеріальних препаратів інших класів (аміноглікозидів, бета-лактамів). Крім того, у зниженні чутливості до хінолонів значну роль може грати й ефлюкс (Kohler et al., 1997).

Широкий спектр клінічних проявів інфекцій, зумовлених ентеробактеріями, потребує інтенсивного вивчення їх ролі у патології людини. Особливого значення ці мікроорганізми набули останніми роками, коли загальна роль умовно-патогенних бактерій у захворюваності людини значно зросла. Особливу увагу ці мікроорганізми привертають через набуття широкого спектра детермінант стійкості до антибіотиків. Багато 3 них на сьогодні володіють стійкістю до декількох препаратів різних груп. До того ж, поширення цих детермінант відбувається доволі активно. У зв'язку з цим особливого значення набуває питання контролю за рівнем розповсюдження антибіотикостійких ізолятів у лікарнях і лікувально-профілактичних закладах, що потребує постійного контролю 3 боку відповідних комітетів при ВООЗ (Yakovlev, 2004).

Деякі антибіотичні препарати застосовують одночасно для посилення ефекту. Зазвичай препарати комбінують у випадку значних інфекційних ускладнень. У дослідах показано, що застосування деяких препаратів поодинці проти збудників інфекційних уражень не ефективне за звичайних концентрацій препарату, комбінація ж двох антибіотиків давала ефект при дозах, що відповідали одній МІК та менше для кожного. Також синергічна дія антибіотиків часто здійснює імуномодулювальний ефект. Переважно порушуються параметри неспецифічних факторів захисту, змінюється імунна відповідь на бактерійні та тканинні антигени. Таку дію антибіотиків можливо упередити застосуванням імуномодуляторів (левамізол, квадевіт). Установлено, що ці препарати дають позитивний ефект (Beloborodova et al., 2000; Stratchounski et al., 2007).

Наслідки впливу антибіотичних речовин у будьякому разі будуть відрізнятися у сполук, що належать до різних класів або у чомусь збігатимуться. Однак ще недостатньо даних (ані експериментальних, ані клінічних) для однозначних висновків щодо впливу препаратів i питання про перевагу використання тих або інших антибіотиків лишається відкритим, тобто проведення антибіотикограми стає обов'язковим дослідженням (Greenwood, 1998; Shapiro, 2002; Bonelli et al., 2014).

\section{Бібліографічні посилання}

Bao, L., Peng, R., Ren, X., Ma, R., Li, J., Wang, Y., 2013. Analysis of some common pathogens and their drug resistance to antibiotics. Pak. J. Med. Sci. 29(1), 135-139.

Beloborodova, N.V., Bohdanov, M.B., Chernenkaia, T.V., 2000. Alhoritmi antibiotikoterapii: Rukovodstvo dlia vrachei [Algorithms of antibiotic therapy: A guide for physicians]. Anteia, Moscow (in Russian).

Bereznyakov, I.G., 2001. Resistentnost k antibiotikam: Prichini, mehanismi, puti preodoleniia [Antibioticresistance: Causes, mechanisms and ways to overcome]. Clin. Antibiotictherapy 4, 18-22(in Russian).

Bonelli, R.R., Moreira, B.M., Picão, R.C., 2014. Antimicrobial resistance among Enterobacteriaceae in South America: History, current dissemination status and associated socioeconomic factors. Drug Resist. Updat. 10 (in Press).

Cochard, H., Aubier, B., Quentin, R., van der Mee-Marquet, N., 2014. Extended-spectrum $\beta$-lactamase-producing Enterobacteriaceae in french nursing homes: An association between high carriage rate among residents, environmental contamination, poor conformity with good hygiene practice, and putative resident-to-resident transmission. Infect. Control Hosp. Epidemiol. 35(4), 384-389.

Decousser, J.W., Pina, P., Picot, F., Delalande, C., Pangon, B., Courvalin, P., Allouch, P., 2003. Frequency of isolation and antimicrobial susceptibility of bacterial pathogens isolated from patients with bloodstream infections: A French prospective national survey. J. Antimicrob. Chemother. 51(5), $1213-1222$. 
Drees, M., Pineles, L., Harris, A.D., Morgan, D.J., 2014. Variation in definitions and isolation procedures for multidrugresistant gram-negative bacteria: A survey of the society for healthcare epidemiology of America Research Network. Infect. Control Hosp. Epidemiol. 35(4), 362-366.

Drlica, K., Zhao, X., 1997. DNA gyrase, topoisomerase IV, and 4-quinolones. Microbiol. Molec. Biol. Rev. 61, 377-392.

Greenwood, D., 1998. Worldwide prevalence of antimicrobial resistance. J. Med. Microbiol. 47(9), 751-755.

Grover, N., Sahni, A.K., Bhattacharya, S., 2012. Therapeutic challenges of ESBLS and AmpC beta-lactamase producers in a tertiary care center. Armed Forces Med. J. India 69(1), 4-10.

Gupta, K., Bhadelia, N., 2013. Management of urinary tract infections from multidrug-resistant organisms. Infect. Dis. Clin. North. Am. 28(1), 49-59.

Kohler, T., Micheahamzehpour, M., Plesiat, P., 1997. Differential selection of multidrug efflux systems by quinolones. Antimicrob. Agents Chemother. 41(11), 2540-2543.

Lee, B., Kang, S.Y., Kang, H.M., Yang, N.R., Kang, H.G., Ha, I.S., Cheong, H.I., Lee, H.J., Choi, E.H., 2013. Outcome of antimicrobial therapy of pediatric urinary tract infections caused by extended-spectrum $\beta$-lactamase-producing Enterobacteriaceae. Infect. Chemother. 45(4), 415-421.

Liu, P.Y., Shi, Z.Y., Tung, K.C., Shyu, C.L., Chan, K.W., Liu, J.W., Wu, Z.Y., Kao, C.C., Huang, Y.C., Lin, C.F., 2014 Antimicrobial resistance to cefotaxime and ertapenem in Enterobacteriaceae: The effects of altering clinical breakpoints. J. Infect. Dev. Ctries. 8(3), 289-296.

Livermore, D.M., 2005. $\beta$-lactamases in laboratory and clinical resistance. Clin. Microbiol. Rev. 8, 557-584.

Miller, G.H., 1996. Nature and rate of aminoglycoside resistance mechanisms. Clin. Drug Invest. 12(1), 1-12.

Nakamura, T., Komatsu, M., Yamasaki, K., Fukuda, S., Higuchi, T., Ono, T., Nishio, H., Sueyoshi, N., Kida, K., Satoh, K., Toda, H., Toyokawa, M., Nishi, I., Sakamoto, M., Akagi, M., Mizutani, T., Nakai, I., Kofuku, T., Orita, T., Zikimoto, T., Natsume, S., Wada, Y., 2014. Susceptibility of various oral antibacterial agents against extended spectrum $\beta$-lactamase producing Escherichia coli and Klebsiella pneumoniae. J. Infect. Chemother. 20(1), 48-51.

Nikaido, H., Nikaido, K., Harayama, S., 1991. Identification and characterization of porins in enterobacteria. Biol. Chem. 266(2), 770-779.

Nikaido, H., Normark, S., 1987. Sensitivity of Escherichia coli to various beta-lactams is determined by the interplay of outer membrane permeability and degradation by periplasmic beta-lactamases: A quantitative predictive treatment. Mol. Microbiol. 1(1), 29-36.

Nilsen, E., Haldorsen, B.C., Sundsfjord, A., Simonsen, G.S., Ingebretsen, A., Naseer, U., Samuelsen, O., 2013. Large IncHI2-plasmids encode extended-spectrum $\beta$-lactamases (ESBLs) in Enterobacter spp. bloodstream isolates, and support ESBL-transfer to Escherichia coli. Clin. Microbiol. Infect. 19(11), E516-518.

Pfaller, M.A., Flamm, R.K., Sader, H.S., Jones, R.N., 2014. Ceftaroline activity against bacterial organisms isolated from acute bacterial skin and skin structure infections in
United States medical centers (2009-2011). Diagn. Microbiol. Infect. Dis. 17, S0732-8893.

Pozdeev, D.C., 2001. Medizinskaia mikrobiolohiia [Medical Microbiology]. Geotar-Med, Moscow (in Russian).

Randrianirina, F., Ratsima, E.H., Ramparany, L., Randremanana, R., Rakotonirina, H.C., Andriamanantena, T., Rakotomanana, F., Rajatonirina, S., Richard, V., Talarmin, A., 2014. Antimicrobial resistance of bacterial enteropathogens isolated from stools in Madagascar. BMC Infect. Dis. 14(1), 104.

Shapiro, A., 2002. Antibiotiki ta ih diia na zbudnikiv oportunistichnih ta nozokomialnih inftkzii [Antibiotics and their effects on opportunistic pathogens and nosocomial infections]. Laboratory Diagnostic. 3, 23-28 (in Ukrainian).

Sidorenko, S.V., 2003. Infekzii, vizivaemie mikroorganizmami semeistva Enterobacteriaceae [Infections caused by microorganisms of the family Enterobacteriaceae]. Clin. Antibiotictherapy 1, 5-9 (in Russian).

Sidorenko, S.V., Rezvan, S.P., Grudinina, S.A., 1998. Sravnitelnaia aktivnost meropenema i druhih antibiotikov v otnoshenii vozbuditelei nosokomialnih infekzii [Comparative activity of meropenem and other antibiotics against nosocomial infections]. Antibiotics and Chemiotherapy 1, 4-14 (in Russian).

Stratchounski, L.S., Belousov, Y.B., Kozlov, S.N. (Eds.), 2007. Prakticheskoe rukovodstvo po antiinfekzionnoi terapii [Practical guidance on antiinfective chemotherapy]. Makmakh, Smolensk (in Russian).

Thibaut, S., Caillon, J., Marquet, A., Grandjean, G., Potel, G., Ballereau, F., 2014. Epidemiology of third-generation cephalosporin-resistant community-acquired Enterobacteria isolated from elderly patients. Med. Mal. Infect. 44(2), 57-62.

Tsiganenko, A.Y., Girich, E.V., 2009. Issledovanie sinerhisma antibakterialnih preparatov, ispolzuemih dlia lecheniia hnoino-vospalitelnih zabolevanii kozhi i miahkih tkanei, vizvannih $E$. coli [Investigation of synergism of antibacterial drugs used for the treatment of inflammatory diseases of the skin and soft tissue caused by E. coli]. Experimental and Clinical Medicine 3, 25-27 (in Russian).

Veldman, K., Kant, A., Dierikx, C., van Essen-Zandbergen, A., Wit, B., Mevius, D., 2014. Enterobacteriaceae resistant to third-generation cephalosporins and quinolones in fresh culinary herbs imported from Southeast Asia. Int. J. Food Microbiol. $177 \mathrm{C}, 72-77$.

Vorobyov, A.A. (Ed.), 2004. Medizinskaia mikrobiolohiia, virusolohiia i immunolohia [Medical microbiology, virology and immunology]. MIA, Moscow (in Russian).

Yakovlev, S.V., 2004. Mesto ftorhinolonov v lechenii bakterialnih infekzii [Place of fluoroquinolones in treatment of bacterial infections]. Russian Medical Journal 11(8), 434-437 (in Russian).

Yakovlev, S.V., 2004. Kakie antibiotiki deistvitelno nuzhni dlia lecheniia urohenitalnich infekzii? [What antibiotics really need for the treatment of urogenital infections?]. Consiliummedicum 6(1), 40-45 (in Russian).

Надійшла до редколегї 02.04.2014 